\title{
Cytotoxicity of triterpenes from the leaves of Garcinia prainiana King (Guttiferae)
}

\author{
Shamsul ON, Wan Mohd Nuzul Hakimi Wan SALLEH, Farediah AHMAD, Hasnah Mohd SIRAT, Muhammad TAHER
}

\begin{abstract}
Phytochemical investigation of the leaves of Garcinia prainiana resulted in the isolation of five triterpenes identified as squalene 1 , friedelin 2 , lupeol 3, 3 $\beta$-hydroxyeupha-5,22-diene 4, and $3 \beta$-acetoxyeupha-5,22-diene 5 . The structures of these compounds were established by analysis of their spectroscopic data, as compared to that of reported compounds. All
\end{abstract}

compounds were tested for cytotoxicity against H1299 and A549 lung cancer cell lines using MTT assay. 3 $\beta$-Acetoxyeupha-5,22diene 5 exhibited the most significant activity against human non-small cell lung carcinoma cell lines, H1299 and A549 with IC $_{50}$ values $18.0 \mu \mathrm{g} / \mathrm{mL}$ and $36.3 \mu \mathrm{g} / \mathrm{mL}$, respectively.

Keywords: Triterpene, Garcinia prainiana, Cytotoxicity
Shamsul On, Wan Mohd Nuzul Hakimi Wan Salleh, Farediah Ahmad, Hasnah Mohd Sirat

Department of Chemistry, Faculty of Science, Universiti Teknologi Malaysia (UTM), 81310 Johor Bahru, Johor, Malaysia

Muhammad Taher

Kulliyyah of Pharmacy, International Islamic University Malaysia, Jalan Sultan Ahmad Shah, Bandar Indera Mahkota, 25200, Kuantan, Pahang, Malaysia

\section{Corresponding author:}

Farediah Ahmad

E-mail:farediah@kimia.fs.utm.my

Tel: +6075534137

Fax: +6075566162

Submitted / Gönderilme: 27.06.2016 Accepted / Kabul: 15.08.2016

Revised / Düzeltme: 09.08.2016

\section{INTRODUCTION}

Triterpenes are naturally occurring alkenes of vegetable, animal and also fungal origin, classified among an extensive and structurally diverse group of natural substances, referred to as triterpenoids. Their structure includes 30 elements of carbon and they are constituted by isoprene units (1-4). Taking into consideration the structure, triterpenes may be divided into linear ones mainly derivatives of squalene, tetracyclic and pentacyclic, containing respectively four and five cycles, as well as two- and tricyclic ones (5). Representatives of those show anticancer (6), anti-inflammatory (7), antioxidative (8), antiviral (9), antibacterial (10) and antifungal activities (11).

The genus Garcinia (Guttiferae) is commonly distributed in tropical and subtropical countries of South East Asia, West and East Africa, in addition to Central and South America (12-13). It is comprises over 400 species in Asia and reported with 49 species from Malaysia region (14). The genus is known for the production of phenolic compounds including xanthones, benzophenones, biflavonoids and depsidones (15). Xanthones are well recognized as chemotaxonomic markers for plants of Garcinia species and many of which have interesting pharmacological effects, including antioxidant, antimicrobial, anti-inflammatory and cytotoxic activities (16-17). Several Garcinia species are used in traditional medicine to cure various ailments such as abdominal pain, dysentery, diarrhoea, infected wound and gonorrhoea (18). 
Garcinia prainiana King (Guttiferae), locally known as cherupu, kechupu or menchupu, is a small tree up to $10 \mathrm{~m}$ tall. The bark produces white exudates and it is scattered in lowland forest throughout Peninsular Malaysia. It grows in similar agroecological tropical conditions as the common mangosteen. It thrives in areas with annual rainfall above 1500 $\mathrm{mm}$ and occurs in many soil types but prefers soils that are porous, deep, wet but well-drained. It occurs wild in lowland forests and on hill sides and ridges up to $900 \mathrm{~m}$ altitude (19). Herein, we report the cytotoxicity of phytochemicals isolated from the leaves $G$. prainiana.

\section{MATERIAL AND METHODS}

\section{Plant material}

Leaves of G. prainiana was collected from Agricultural Garden, Kuantan, Pahang in November 2009 and identified by Dr. Muhammad Taher. The voucher specimens (MT27) were deposited at the herbarium of Kulliyyah of Pharmacy, International Islamic University, Malaysia.

\section{General experimental procedures}

Silica gel $60 \mathrm{~F}_{254}$ precoated aluminium plates $(0.2 \mathrm{~mm}$, Merck) were used for TLC analysis. The TLC and PTLC spots were visualized under UV light (254 and $366 \mathrm{~nm}$ ) followed by spraying with $5 \% \mathrm{H}_{2} \mathrm{SO}_{4}$ in methanol and $1 \%$ vanillin in $\mathrm{MeOH}$, followed by heating at $120^{\circ} \mathrm{C}$ for $5 \mathrm{~min}$. Vacuum Liquid Chromatography (VLC) was carried out on silica gel 230-400 mesh (Merck) while Column Chromatography was carried out on silica gel 70-230 mesh (Merck). The UV spectra were obtained in methanol on a Shimadzu UV 1601PC spectrophotometer. The IR spectra were obtained on a Perkin-Elmer 1600 FTIR spectrophotometer. The mass spectra were recorded on Bruker Mass Spectrometry Services, obtained from National University of Singapore (NUS). The ${ }^{1} \mathrm{H}-\mathrm{NMR}$ and ${ }^{13} \mathrm{C}-\mathrm{NMR}$ spectra were recorded in deuterated chloroform on a Bruker Avance $400 \mathrm{MHz}$ spectrometer, chemical shifts are reported in ppm on $\delta$ scale, and the coupling constants are given in $\mathrm{Hz}$. All solvents were analytical reagent grade.

\section{Extraction and isolation procedures}

The dried and powdered leaves of G. prainiana (300 g) were extracted using a Soxhlet extractor for $9 \mathrm{~h}$ each with $n$-hexane, dichloromethane (DCM) and $\mathrm{MeOH}$ (2.5 L each) successively at room temperature. Concentration of each solvent under reduced pressure afforded a crude $n$-hexane (10 g), DCM (7 g) and MeOH extract (18 g), all as gummy dark green liquid. The $n$-hexane extract $(8 \mathrm{~g})$ was submitted to VLC on silica gel using a gradient of $n$-hexane: $\mathrm{CHCl}_{3}$ :EtOAc to yielded thirteen fractions. Fraction 3-7 (180 mg) was combined and separated using silica gel CC (diameter 3.0 $\mathrm{cm}$, length $50 \mathrm{~cm}$ ) using a gradient of $n$-hexane: $\mathrm{CHCl}_{3}$ to give seventy sub-fractions. Sub-fraction 5-30 (75 mg) showed the existence of two major components on TLC (hexane: $\mathrm{CHCl}_{3}$ ) and was submitted for further purification by CC (diameter $1.5 \mathrm{~cm}$, length $40 \mathrm{~cm}$ ) eluted with a gradient hexane: $\mathrm{CHCl}_{3}$ to produced 1 (14 mg) and 2 (30 mg). Sub-fraction 33-45 (100 mg) was applied to silica gel CC (diameter $1.5 \mathrm{~cm}$, length $40 \mathrm{~cm}$ ) eluted with $n$-hexane: $\mathrm{CHCl}_{3}$ to furnish 3 (15 mg). The $\mathrm{MeOH}$ extract (10 g) was submitted to VLC on silica gel using gradient of $\mathrm{CHCl}_{3}$ :EtOAc (95:5, 90:10, $80: 20,70: 30,60: 40,50: 50,40: 60,20: 80,0: 100)$ to furnish nine fractions. Fraction 3-5 (150 mg) was combined and applied to silica gel CC (diameter $2.5 \mathrm{~cm}$, length $45 \mathrm{~cm}$ ) eluted with $\mathrm{CHCl}_{3}: \mathrm{MeOH}$ led to the isolation of $4(15 \mathrm{mg})$ and 5 (20 $\mathrm{mg}$ ). The identification of isolated compounds was achieved by UV, IR, MS, ${ }^{1} \mathrm{H},{ }^{13} \mathrm{C}$ NMR and $2 \mathrm{D}$ NMR methods. Their structures were confirmed by comparisons with reported data.

\section{Cytotoxic assay}

The assay against human non-small cell lung carcinoma cell lines H1299 and A549 were conducted using the 3-(4,5-dimethylthiazol-2-yl)-2,5-diphenyltetrazolium bromide (MTT) test according to Mosmann et al. (20). The monolayer cell lines were cultured in DMEM supplemented with $10 \%(\mathrm{v} / \mathrm{v})$ foetal bovine serum and antibiotic $(1 \%$ penicillin-streptomycin) in a 96 -well plate at a density of $2 \times 10^{4}$ cells $/ \mathrm{mL}$. After reaching confluence $\left(2 \times 10^{5}\right.$ cell $\left./ \mathrm{mL}\right)$, then the cells were treated with the samples. The tested compounds were dissolved in DMSO $(1 \mathrm{mg} / \mathrm{mL})$. Each compounds were treated in triplicates with serial dilution of sample (0.01-1 $\mathrm{mg} / \mathrm{mL}$ ) for $24 \mathrm{~h}$. Doxorubicin was used as a commercialized anticancer standard. To reduce the interference of residue of supernatant, the monolayer cell lines was washed two times with phosphate buffer saline (PBS), the $20 \mathrm{ml}$ of MTT stock solution $(5 \mathrm{mg} / \mathrm{mL})$ was added and the plates were further incubated overnight at $37^{\circ} \mathrm{C}$. DMSO $(100 \mathrm{~mL})$ was added to each well to dissolve the purple formazan crystal. After $1 \mathrm{~h}$, the solubilized formazan was measured at 570 and $630 \mathrm{~nm}$ (reference) with a UV microplate reader. The half reduction in cell number relative to control or $\mathrm{IC}_{50}$ was established by extrapolation from linear regression of experimental data.

\section{Scanning Electron Microscopy}

In brief, about $2.5 \mathrm{~mL}$ of confluent cell was transferred into a 
6-well plate, which contained sterile cover slips at the bottom of the wells, and incubated overnight in $\mathrm{CO}_{2}$ incubator at $37^{\circ} \mathrm{C}$. The seeded cell was treated with sample/standard using the $\mathrm{IC}_{50}$ value to make sure that just $50 \%$ of the treated cell will inhibit and incubated with media again for overnight. Then the media and sample/standard were discarded and washed with phosphate buffer. Then, McDowell and Trump fixative was added and it was kept overnight. Then the fixative was removed gently and washed with cacodylate buffer for two times. Then, a $1 \mathrm{mg} / \mathrm{mL}$ of osmium tetraoxide was added in small volume just to cover the surface for 1 h. After that, a double-distilled water was used for washing to remove the excess of osmium tetraoxide for 3 times. Afterward, the dehydration process was started by washing with $50 \%$ ethanol for 15 min once, followed by $75 \%$ ethanol for $15 \mathrm{~min}$ once, followed by $95 \%$ ethanol for $20 \mathrm{~min}$ for 3 times, and then followed by absolute ethanol for $20 \mathrm{~min}$ for 3 times. Finally, $0.5 \mathrm{~mL}$ HMDS was added and left uncovered overnight. After that, the cover slip was taken out and coated with gold in a Baltec-CED 030 and viewed by Carl Zeiss Evo 50 Scanning Electron Microscopy (21-22).

\section{Statistical analysis}

Data obtained from cytotoxicity was expressed as mean values. The statistical analyses and significance of the results was determined using a one way ANOVA ( $p>0.05)$. A statistical package (SPSS version 11.0) was used for the data analysis.

\section{RESULTS AND DISCUSSION}

The structures of the triterpenes were elucidated on the basis of $1 \mathrm{D}$ and 2D NMR data and by comparisons with published data. The compounds were characterized as squalene $\mathbf{1}$, friedelin 2, lupeol 3, 3 $\beta$-hydroxyeupha-5,22-diene 4 and $3 \beta$-acetoxyeupha-5,22-diene 5 (Figure 1). Mawa and Said, (23) have reported the isolation of friedelin, eupha-8,24-diene$3 \beta$-ol, stigmasterol, teraxerone and teraxerol from the twigs of G. prainiana, while Susanti et al. (24) isolated friedelin and lanosterol from the same part. Previous studies also reported that the methanol leaf extract of G. prainiana exhibited an inhibition against nitric oxide production (25), while the leaf and fruit extracts were found to exhibit antioxidant capacity (26). In addition, the twig extracts have shown significant $\mathrm{DPPH}$ radical scavenging with $\mathrm{IC}_{50}$ value 2.9 ( $\mathrm{MeOH}$ extract) and 1.9 (EtOAc extract) $\mu \mathrm{g} / \mathrm{mL}(26)$. With the interest in the chemotaxonomy and biomedical potential of Garcinia, the present study was conducted to search for potential compounds which are cytotoxic to human lung cancer. The isolated compounds were subjected to cytotoxicity screening against human lung cancer H1299 and A549 cell lines. Table 1 shows the cytotoxic activity of the isolated compounds. Compounds $\mathbf{1}$ and $\mathbf{5}$ were found to have significant activity towards both cell lines. Compound 5 shown the best activity with $\mathrm{IC}_{50}$ values of 18.0 and $36.3 \mu \mathrm{g} / \mathrm{mL}$, against $\mathrm{H} 1299$ and A549 cell lines, respectively. Compound 1 gave $\mathrm{IC}_{50}$ values of $23.2 \mu \mathrm{g} / \mathrm{mL}$ (H1299) and $74.8 \mu \mathrm{g} / \mathrm{mL}$ (A549). The most active compounds (1 and $\mathbf{5}$ ) showed more activity against H1299 than A549 cell lines. Scanning electron microscope has been done on the cells after treatment with $\mathbf{1}$ and $\mathbf{5}$ as shown in Figure 2. Both compounds induced apoptosis on H1299 and A549 indicated by blebbing phenomenon, a specific pattern on apoptosis (27). Cytotoxic activity has also been observed in derivatives of linear squalene. Apart from the inhibitory role, squalene also shows the capability of inducing apoptosis in many neoplastic lines: leukemia, melanoma, colon cancer, prostate cancer, ovarian carcinoma, liver cancer, breast cancer, lung cancer and peripheral nervous system carcinoma (28). Triterpenes are natural compounds showing a wide spectrum of biological effects. They proved to have antibacterial, antiviral, antifungal, antioxidative and anti-inflammatory properties, as well as anticancer and chemopreventive ones (29).

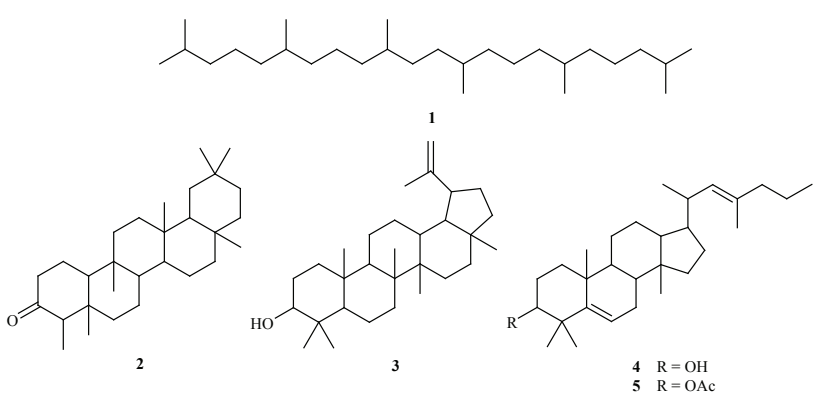

Figure 1. Chemical structures of triterpenes isolated from $G$. prainiana

Table 1. Cytotoxicity activity of triterpenes isolated from $G$. prainiana

\begin{tabular}{lcc}
\hline Compounds & \multicolumn{2}{c}{$\mathrm{IC}_{50}(\mu \mathrm{g} / \mathrm{mL})$} \\
\cline { 2 - 3 } & H1299 & A549 \\
\hline $\mathbf{1}$ & $23.2 \pm 2.1$ & $74.8 \pm 3.4$ \\
$\mathbf{2}$ & $163.9 \pm 1.9$ & $254.7 \pm 2.1$ \\
$\mathbf{3}$ & $126.1 \pm 1.3$ & $110.2 \pm 0.2$ \\
$\mathbf{4}$ & $103.2 \pm 1.6$ & $156.5 \pm 0.4$ \\
$\mathbf{5}$ & $18.0 \pm 1.7$ & $36.3 \pm 2.6$ \\
Doxorubicin & $10.0 \pm 0.1$ & $2.38 \pm 0.2$ \\
\hline
\end{tabular}

Each value represents the mean \pm SD. 
(A)

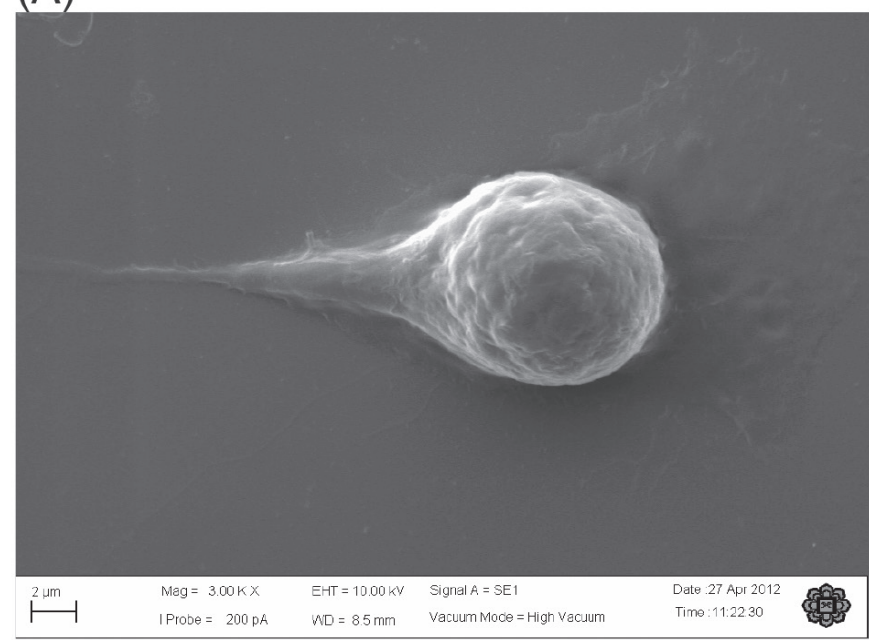

(C)

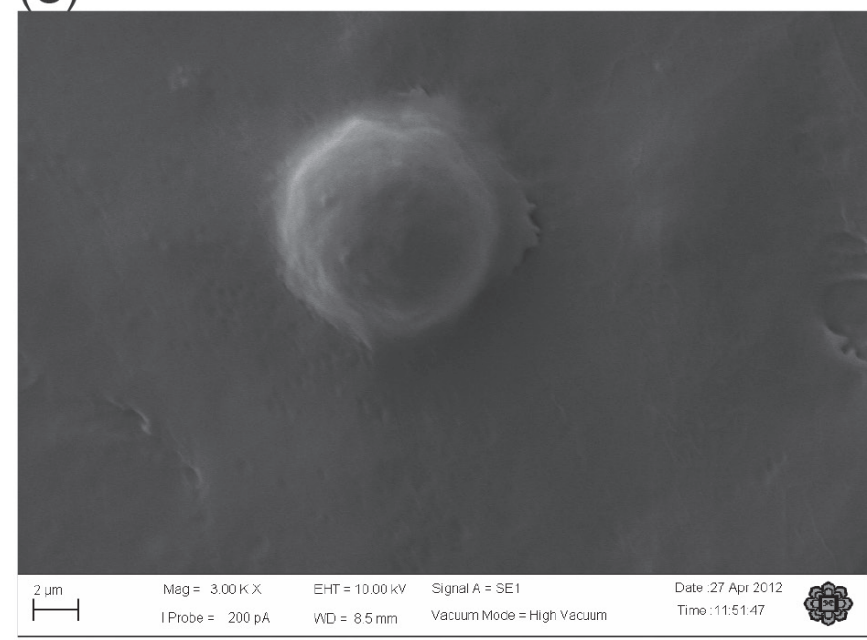

(B)

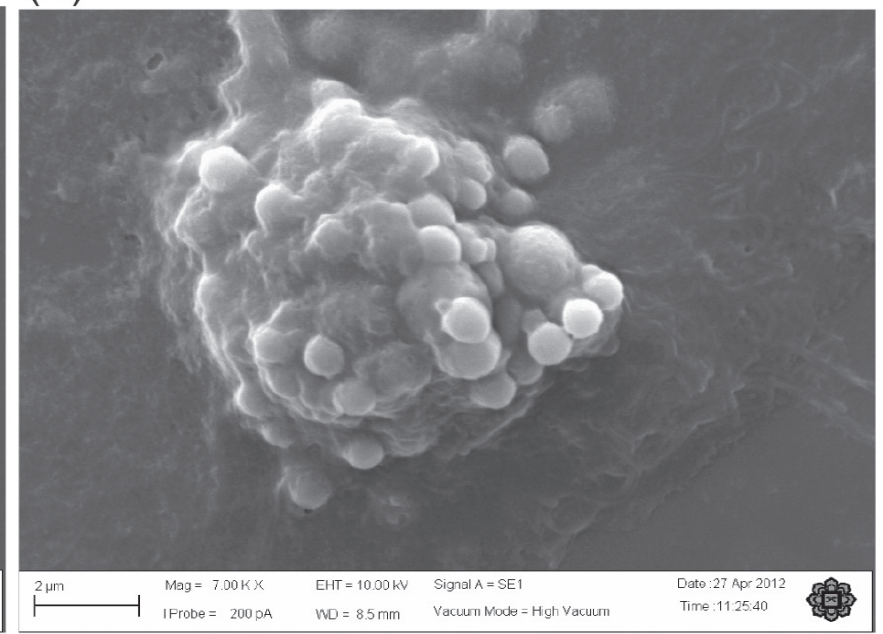

(D)

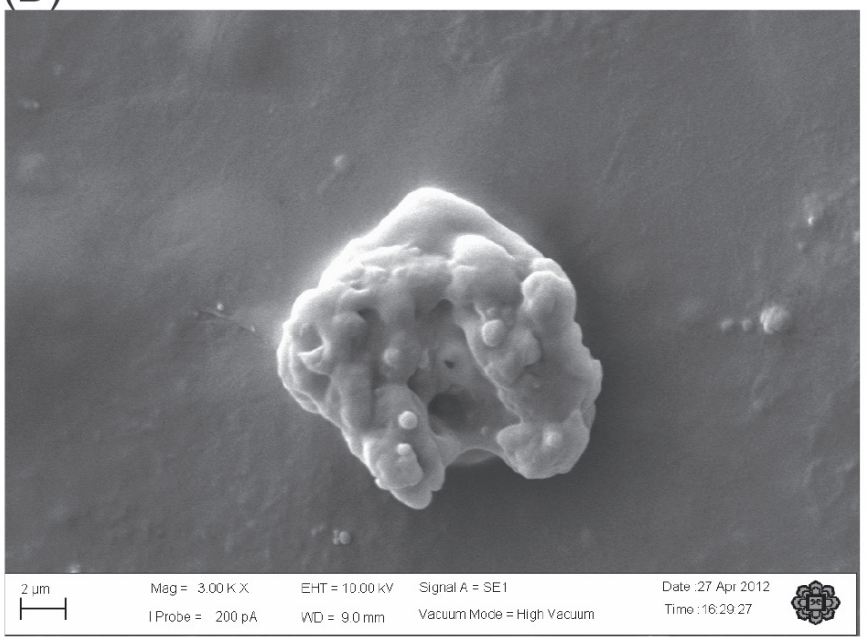

Figure 2. Cell membrane blebbing during apoptosis after treated with $100 \mu \mathrm{g} / \mathrm{mL}$ of $\mathbf{1}$ and $\mathbf{5}$. (A) H1299 (untreated with $\mathbf{1}$ ) (B) H1299 (treated with 1) (C) A549 (untreated with 5) (D) A549 (treated with 5).

\section{CONCLUSION}

This study investigated the isolated triterpenes from $G$. prainiana and their cytotoxicity. The cytotoxicity evaluation of isolated pure compounds provides valuable information regarding the prospective use of medicinal plants as sources

Garcinia prainiana King (Guttiferae) Yapraklarından Elde Edilen Triterpenlerin Sitotoksik Özellikleri

\section{ÖZ}

Garcinia prainiana yapraklarını konu alan fitokimyasal araştırmalar sonucunda triterpen yapısında beş bileşik izole edilmiştir; skualen 1 , friedelin 2 , lupeol $3,3 \beta$-hidroksiöfa5,22-dien 4, and $3 \beta$-asetoksiöfa-5,22-dien 5 . İzole edilen of new drugs. Also, it emphasizes the rationale for using medicinal plants in folk medicine. The cytotoxicity of isolated compounds may validate the traditional use of the plant as an anticancer agent. Therefore, more directed research is needed to explore the ability of plants to enhance the discovery and development of new chemical entities.

bileşiklerin yapıları spektroskopik yöntemler kullanılarak aydınlatılmış ve elde edilen sonuçlar yukarıda belirtilen bileşiklere ait spektroskopik verilerle karşılaştırılmıştır. Tüm bileşiklerin, H1299 ve A549 akciğer kanseri hücre hatları üzerindeki sitotoksik etkileri MTT yöntemiyle çalışılmıştır. 3ß-Asetoksiöfa-5,22-dien 5, H1299 ve A549 hücre hatlarına karşı sırasıyla $\mathrm{IC}_{50}=18.0 \mu \mathrm{g} / \mathrm{ml}$ ve $\mathrm{IC}_{50}=36.3 \mu \mathrm{g} / \mathrm{ml}$ derişimde etki göstererek serisindeki en etkili bileşik olarak öne çıkmıştır.

Anahtar kelimeler: Triterpen, Garcinia prainiana, Sitotoksisite. 


\section{ACKNOWLEDGEMENTS}

The authors are grateful to Research University Grant (GUP), from the Ministry of Higher Education (MOHE) under vote Q.J130000.2526.03H93 for financial support and Faculty of Science, Universiti Teknologi Malaysia for research facilities.

\section{REFERENCES}

1. Rhourri-Frih B, Renimel I, Chaimbault P, André P, Herbette G, Lafosse M. Pentacyclic triterpenes from Manilkara bidentata resin. Isolation, identification and biological properties. Fitoterapia 2013; 88: 101-8.

2. Silchenko AS, Kalinovsky AI, Avilov SA, Andryjaschenko PV, Dmitrenok PS, Martyyas EA, Kalinin VI. Triterpene glycosides from the sea cucumber Eupentacta fraudatrix. Structure and biological action of cucumariosides I1, I3, I4, three new minor disulfated pentaosides. Nat Prod Commun 2013; 8: 1053-8.

3. Kim KH, Moon E, Choi SU, Kim SY, Lee KR. Lanostane triterpenoids from the mushroom Naematoloma fasciculare. J Nat Prod 2013; 76: 845-51.

4. McMurry J. Chemia Organiczna, 3rd ed. Wydawnictwo Naukowe PWN, Warszawa, Poland. 2005.

5. Breitmaier E. Terpenes: Flavors, Fragrances, Pharmaca, Pheromones, 1st ed. Wiley-VCH Verlag GmbH \& Co. KGaA Weinheim, Germany. 2006.

6. Fulda S. Betulinic acid: A natural product with anticancer activity. Mol Nutr Food Res 2009; 53: 140-6.

7. Liaw CC, Chen YC, Huang GJ, Tsai YC, Chien SC, Wu JH, Wang SY, Chao LK, Sung PJ, Huang HC, Kuo YH. Antiinflammatory lanostanoids and lactone derivatives from Antrodia camphorata. J Nat Prod 2013; 76: 489-94.

8. De Silva ML, David JP, Silva LC, Santos RA, David JM, Lima LS, Reis PS, Fontana R. Bioactive oleanane, lupane and ursane triterpene acid derivatives. Molecules 2012; 17: 12197-205.

9. Baltina LA, Flekhter OB, Nigmatullina LR, Boreko EI, Pavlova NI, Nikolaeva SN, Savinova OV, Tolstikov GA. Lupane triterpenes and derivatives with antiviral activity. Bioorg Med Chem Lett 2003; 13: 3549-52.

10. Ahmed Y, Sohrab MH, Al-Reza SM, Tareq FS, Hasan CM, Sattar MA. Antimicrobial and cytotoxic constituents from leaves of Sapium baccatum. Food Chem Toxicol 2010; 48: 54952.

11. Mokoka TA, McGaw LJ, Mdee LK, Bagla VP, Iwalewa EO, Eloff JN. Antimicrobial activity and cytotoxicity of triterpenes isolated from leaves of Maytenus undata (Celastraceae). BMC Complement Altern Med 2013; 13: doi:10.1186/1472-688213-111.

12. Chudzik M, Korzonek-Szlacheta I, Król W. Triterpenes as potentially cytotoxic compounds. Molecules 2015; 20: 161025.

13. Ampofo SA, Waterman PG. Xanthones from three Garcinia species. Phytochemistry 1986; 25: 2351-5.
14. Whitmore TC. Tree Flora of Malaya 2: A Manual for Foresters. Longman Malaysia, Kuala Lumpur. 1973.

15. Peres V, Nagem TJ, Faustino de Oliveira F. Tetraoxygenated naturally occuring xanthones. Phytochemistry 2000; 55: 683710.

16. Panthong K, Pongcharoen W, Phongphaichit S, Taylor WC. Tetaroxygenated xanthones from the fruits of Garcinia cowa. Phytochemistry 2006; 67: 999-1004.

17. Tian Z, Shen J, Moseman AP, Yang Q, Yang J, Xiao P, Wu E, Kohane IS. Dulxanthone A induces cell cycle arrest and apoptosis via up-regulation of p53 through mitochondrial pathway in HepG2 cells. Int J Cancer 2008; 122: 31-8.

18. Jayaprakasha GK, Negi PN, Jena BS. Antioxidative and antimutagenic activities of the extracts from the rinds of Garcinia penduculala. Innov. Food Sci Emerg Technol 2006; 7: 246-50.

19. Burkill IH. A dictionary of the economic products of the Malay Peninsula. Ministry of Agriculture and Co-operatives, Kuala Lumpur. 1966.

20. Mosmann T. Rapid colorimetric assay for cellular growth and survival: Application to proliferation and cytotoxicity assays. J Immun Methods 1983; 65: 55-63.

21. Nottola SA, Makabe S, Stallone T, Familiari G, Correr S, Macchiarelli G. Surface morphology af the zona pellucida surrounding human blastocysts obtained after in vitro fertilization Arch Histol Cytol 2005; 68: 133-41.

22. Taher M, Susanti D, Rezali MF, Zohri FS, Ichwan SJ, Alkhamaiseh SI, Ahmad F. Apoptosis, antimicrobial and antioxidant activities of phytochemicals from Garcinia malaccensis Hk.f. Asian Pacific J Trop Med 2012; 5: 136-41.

23. Mawa S, Said MI. Chemical constituents of Garcinia prainiana. Sains Malay 2012; 41: 585-90.

24. Susanti D, Ali MZ, Amiroudine M, Rezali MF, Taher M. Friedelin and lanosterol from Garcinia prainiana stimulated glucose uptake and adipocytes differentiation in 3T3-L1 adipocytes. Nat Prod Res 2013; 27: 417-24.

25. Jabit ML, Wahyuni FS, Khalid R, Israf DA, Shaari K, Lajis NH, Stanslas J. Cytotoxic and nitric oxide inhibitory activities of methanol extracts of Garcinia species. Pharm Biol 2009; 47: 1019-26.

26. Klaiklay S, Sukpondma Y, Rukachaisirikul V, HutadilokTowatana N, Chareonrat K. Flavanone glucuronides from the leaves of Garcinia prainiana. Canadian J Chem 2011; 89: 4614.

27. Susanti D, Taher M, Attoumani N, Ahmad F. Free radical scavenging and antibacterial activities of Malaysian guttiferae plants. J Med Pl Res 2011; 5: 6714-8.

28. Reddy LH, Renoir JM, Marsaud V, Lepetre-Mouelhi S, Desmaele D, Couvreur P. Anticancer efficacy of squalenoyl gemcitabine nanomedicine on 60 human tumor cell panel and on experimental tumor. Mol Pharm 2009; 6: 1526-35.

29. Chudzik M, Korzonek-Szlacheta I, Krol W. Triterpenes as potentially cytotoxic compounds. Molecules 2015; 20: 161025. 